\title{
New Approach to State Protection of Competition
}

\author{
Adalat Muradov', Rovshan Akbarov², Nazim Hajiyev ${ }^{3,4}$ \\ ${ }^{1}$ Dr. of Econ., Prof., Rector of Azerbaijan State University of Economics (UNEC), Baku, Republic of \\ Azerbaijan, Istiglaliyyat str.6, AZ1001,E-mail:adalet_muradov@yahoo.com \\ ${ }^{2}$ Dr. associate professor, Deputy Director of the Distance, correspondence and additional professional education \\ Center of Azerbaijan State University of Economics (UNEC), Baku, Republic of Azerbaijan, Istiglaliyyat str. 6 , \\ AZ1001, \\ ${ }^{3}$ Dr. associate professor, Department of Economics and Business management, Azerbaijan State University of \\ Economics, Baku, Azerbaijan. \\ ${ }^{4}$ Visiting Scholar, Davis Center for Russian and Eurasian Studies, Harvard University, Boston, USA, E-mail: \\ n.hajiyev@unec.edu.az,nazimhajiyevaz@gmail.com
}

Article History: Received: 10 November 2020; Revised 12 January 2021; Accepted: 27 January 2021; Published online: 5 April 2021

\begin{abstract}
The aim of the article is to improve the possibilities for learning and applying practical tips on competition protection, and to develop ways to promote competition and economic growth that will enhance the prosperity of the economy and society. It is important that the goal of competition protection is to create conditions that will lead to a more competitive market structure and business behavior without direct intervention from the competition body. Note that the most disadvantageous alternative to the competition body is the application of close and lasting control of the dominant firms by competition law. This alternative results in more inadequate funding by requiring more resources. Modern economic reality, characterized by the transformation of economic relations, business globalization, integration of transitional economies into the global space, makes the development of competitive relationships more important for improving economic and innovation performance. As a result, it has been established that a successful market economy requires a competitive culture within the country. Both consumers and the business community need to be aware of their competitive policies and how they can benefit from it. Competition agencies play an important role in this learning process.
\end{abstract}

Keywords

efficient market economy, sound competition policy, protection of competition, economic policy, competitive market

\section{Introduction}

As it is known, monopoly and unfair competition are acknowledged in the Constitution of the Republic of Azerbaijan as one of the strategic tasks of the state [Article 15.2.]. Article 15.2 of the Constitution provides for the formation of competition as an essential part of an effective market economy mechanism.

One of the fundamental conditions and factors of efficient market economy is a sound competition policy and environment. This is an indicator of the positive experience of world economic development and is a problem that is becoming increasingly relevant in modern economic thought and economic policy. The transitional economy, the development and protection of competition in emerging and developed countries are carried out in different dimensions and dimensions. Supporting competition in a country with more than one hundred years of concrete experience in this field and helping small entrepreneur's to enter the competitive market are included in the functions of the federal government's economic regulation [Legal regulation of the competition process. New York et al]. $\mathrm{n}$ a country with more than one hundred years of experience in the area, such as the United States, promoting 
federal competition and helping small businesses enter the competitive market is part of the federal government's economic regulatory functions. Nearly 90 countries have adopted specific laws on competition protection and 30 countries are on the verge of accepting those laws [Economic Report of the President Washington, 2000].

The laws of the Republic of Azerbaijan "On anti-monopoly activity", "On unfair competition", "On natural monopolies", "On protection of consumers' rights", "Advertising" were adopted and thus the formation of the legislative mechanism of competition mechanism was completed. The globalization process, which has become a subject of intensive discussions around the world on competition protection, is being strengthened by a global market economy mechanism. United Nations Conference on Trade and Development (UNCTAD), Organization for Economic Cooperation and Development (OECD); Authoritative international organizations such as the World Trade Organization (WTO) and the World Bank have intensified their activities in this area. A large amount of literature is published on existing legislation, policy and action [Policy directions for global merger review. London. 1999 et al.].

In addition to expanding the geography of countries joining the competition policy, competition policies are also improving. Since traditional anti-monopoly measures and norms are not adequate today, the need for intensification of competition mechanisms is one of the implications of the trends in the global economy.

It should be noted that international conference, symposium and workshops were held in Bankonda, Chaypur (India), Istanbul, Casablanca, Kiev, Moscow, San Jose (Costa Rica) and other cities. Several conferences on Geneva-based United Nations conferences on "Review of all aspects of the integrated control principles and rules complex on multilateral basis for restrictive business practice" were held in Geneva.

In our opinion, all this is not temporary and casual. Although the market economy and economic competition are the basis of economic globalization, the ratio of "participation" and "benefit" of individual countries in this process is not the same. Although globalization is strengthening, but the sharing of economic powers and capacities between the countries, and their convergence is almost non-existent [Remarks by the President at world economic forum. Davos, 2000. China and India's economic development did not change this trend substantially. Most of the elements of the problems mentioned in the article were mentioned in the scientific works and scientific views of several economists. Muradov, A.J., Hajiyev N.O. (2014), Lal K Almas, Hajiyev N.O.(2013) considered important to development of competition.

In countries with the best competition protection legislation, consistent oversight of competition in domestic markets, the state is trying to create favorable conditions for their national companies in the system of international relations and becomes their carrier of their interests. From this point of view, the world is shaping in the marketplace freedom of competition and fair competition meet objectively strong obstacles.

The relationship between competition policy and competition law, which expresses the relationship between competition development and competition protection is multifaceted. Without a doubt, something else can be maintained and at the same time, the protected thing can grow. Despite the different concepts, competition, anti-monopoly and other similar laws are directly aimed at protecting competition. Legislation on Japan [ Antimonopoly legilation of Japan. Tokyo,1998.] and Azerbaijan and Anti-Monopoly Legislation have been drafted and the relevant legislation of Turkey and Bulgaria [Commission for the Protection of Competition. Sofia 1994, Protection of competition qanunu. Ankara 1998] has been formulated under the so-called "competition protection". Development coopetition problems of the national economy took the place in the scientific works of Muradov. A.J. Hajiyev N.O. (2013), Muradov A.J., Hasanli Y.H., Hajiyev N.O. (2019), Muradov, A.J., Hajiyev 
N.O.(2014), Hajiyev N.O.(2012) considered important to place greater emphasis on competition and diversification of economic development. There is no difference between them functionally. In either case, the conversation is about competition protection. As a result of the application of competition law, competition is evolving. Therefore, in a broad sense, competition protection is part of the development of competition.

State agency, which carries out state protection of the competition, has already been formally organized. The purpose of the commodity market research and the establishment of a mechanism for controlling various types of transactions and combinations is to determine the status of competition and the level of economic concentration in the domestic market. A group of professionals that will solve these issues, which form the most complex component of our state's micro-regulatory activities, has already been formed.

The concept of competition is actively absorbed by our entrepreneurs and becomes an integral part of their behavioral norms. Our honest entrepreneurs require rigorous action against unfair competition. The domestic market of Azerbaijan has become a competitive place as a result of privatization of state property and restructuring of various state-owned companies and large companies. Strengthening of the activity of newly established business entities is a factor of development of competition. Radical results have been gained in the separation of government regulation functions that have substantially restricted the division of discrimination directly arising from administrative cases. As a result of transforming the Azerbaijani economy into a competitive sphere of foreign companies and transnational corporations, various competitive segments have emerged in the domestic market.

In addition to this, the spectrum of works to bring the competition into effective development of state protection is quite broad.

State regulation of competition is one of the means of state protection in one or another form. The issue of fair protection is also part of the current strategic development challenges of the 21 st century. This is the necessity of the economic development of emerging economic globalization and, consequently, due to the consistent integration of world markets with the diversity of competitiveness and rapid expansion of transnational corporations.

Different countries have varying levels of competitiveness depending on the level of economic development and the size of the domestic market. One of the goals of attracting foreign investment in a country like the United States is the protection and promotion of competition. Because the existing competitive environment in our country is a type of competitive competition, foreign investment in the country cannot be directly targeted at competition. The key issue here is to strengthen competition in the marketplace and to shape the behavior, behavior, and capabilities of our national entrepreneurs. Therefore, all our actions should be carried out within the objective of an imperfect competitive model. In such circumstances, world practice shows that the behavior of market subjects and companies in the market is conditioned by more market structure. Despite the fact that a large majority of transnational companies focusing on the development of around 40,000 world economies are concentrated in developed countries, the effectiveness of small businesses in these countries is higher than in developing countries.

Under current conditions, it is advisable to implement a soft anti-monopoly policy, taking into account the stage of competition in our country. Taking into account that the tendency to reach a dominant position in the domestic market for market conditions is natural and this is an economic growth and progress factor, it is unacceptable to prevent this process as a whole. In accordance with the Decree "On state regulation of prices (tariffs) of products (services) of monopoly enterprises and associations," state regulation of economic entities with dominating position does not apply to new and high category products for 2 years from the date of their production. It is envisaged that the state regulation of the domestic market will be applied only to economic entities that use abusive power. 
However, it is important that strict measures be taken to protect the competition while investigating the competition situation in the domestic market, such as tea, water, butter and others. In order to eliminate the violations of the requirements of the anti-monopoly legislation, various economic entities have been instructed to carry out about 40 operations. Implementing these guidelines often obviates great obstacles.Despite the demonopolzation of some of the key sectors of the economy during privatization, anti-monopoly legislation was still widespread. Because of the limited demand for large enterprises in the domestic market, they are weakly involved in the formation of a competitive environment. Therefore, in addition to implementing a broader anti-monopoly policy, it is also necessary to apply harsh measures in this area.

Implementation of entrepreneurship and economy and transition of concessionary measures in the context of transitional economy does not violate the competitive environment itself, but rather contributes to its development. In all developed countries, such measures are undertaken in different ways and at different dimensions. 85 of the subsidies given to the export of agricultural products in the world fall to the European Union. That's why it is very important for us to take such measures. Effective application of incentive measures in current conditions is a problematic issue. In accordance with anti-monopoly legislation of the Republic of Azerbaijan, the use of incentive measures in unfounded and discriminatory circumstances is considered illegal.

In any case, direct concessions and concessions to any company mean a gross violation of the legislation of the Republic of Azerbaijan. At the same time, the relevant legislative framework of the sectors of the economy as well as regional problems has been formed, which in itself does not prevent competition conditions. Although it does not have a specific legislative framework regulating the process of helping the start-up of new start-up entrepreneurs needed economically in our country, its implementation contradicts the antimonopoly legislation. The recent adoption by the Milli Mejlis of the Law on State Assistance to Small Enterprises, despite the serious steps taken in this direction, does not eliminate the existing legal-normative gap.

At present, more than 40 state agencies in our country have the right to control certain areas, conditions and factors of entrepreneurship in some way. In practice, this is an automatic verification of entrepreneurs' activity. Some companies may, in some ways, be outside the control of the inspectors. As a result, unreasonable competition conditions for economic subjects are created. This form of discrimination is widely spread in the CIS and its tendency to strengthen. Therefore, the requirements of the Decree of the President of the Republic of Azerbaijan "On the elimination of artificial obstacles in the area of improvement of the state control system and the development of entrepreneurship" should be applied with full force. At the same time, the borders between the functions of regulatory subdivisions of regulation and control of the subdivision should be expressed in normative documents. The direction of the audit should be transparent to the transparent regulatory framework and the circumstances underlying the inspection should be determined.

In general, the mechanism of development and protection of competition in our country is formed under the influence of a variety of contradictory factors, which will continue in the coming years as well. Therefore, according to the duties and powers of the State Service for Antimonopoly Policy and Consumer Protection under the Ministry of Economy, the nomenclature of activities in this field should be expanded. Above all, the analytical research base of the competition mechanism should be expanded. Certainly, there is no need to be able to deal with issues of monopoly and competition theory today. These issues are sufficiently illuminated in the world economic thought to take action. But in any case, the model and its level, which is shaped in Azerbaijan, must be studied and evaluated on a consistent basis. The development and protection of competition with the anti-monopoly policy inherited in the 
first period was mainly concentrated on the non-monopolization of the economy for objective reasons. New aspects of the issue that do not lose its relevance will be revealed. Antimonopoly measures are already part of the competing mechanism. The services provided by state monopoly that do not have a competitive sphere have an impact on the formation of a competitive mechanism and the interests of entrepreneurs. Therefore, the principles and normative base of tariffs for these services should be established. Licensing activity, which is a direct attribute of entrepreneurship, is one of the factors influencing the formation of competition in the market as well as in its field and regional segments. This area has also reached a level of systematization. There is a need to discuss a number of principal issues to clarify the licensing functions and nomenclature. A wide inventory of other situations that result in "monopolistic behavior" and "competition infringement" in the domestic market should be completed. Although the competitiveness criteria for our economy are generally defined, it needs to be strictly accurate in line with its structural policy. Evaluating the competitiveness of goods and companies that have an impact on the domestic market should be systematized and the factors of national competitiveness should be assessed. Improving the legislative framework of the competition mechanism is also a challenge. One of the foremost issues is the creation of a special legislative framework for the protection of competition in the financial services market. Article 9 of the Law of the Republic of Azerbaijan "On Anti-Monopoly Activities" has identified some illegal acts limiting the competition of differentiated financial-credit organizations. However, it can be found in very limited cases. This does not allow the regulation of the financial services market to be adapted to the competitive environment. Measures to regulate competition monopoly in competitive conditions should also be brought into the system.

At present, a methodological basis is being developed to address the obstacles to entry into the market of new business entities and to expose them to corruption.

The database should be expanded to prevent and control the timely containment of key compounds that may be potentially competitive for the domestic market, and a number of specific research mechanisms should be established.

\section{Results, Conclusions and Recommendations}

The application of competition law is both a good base and a means to strengthen sustainable competitive markets resulting in healthy competition, opportunities for new incomes, entrepreneurship, high economic efficiency and consumer welfare. Competition protection can increase these or other benefits of competition. Experience shows that a number of factors lead to the protection of successful competition:

- The Competition Agency should develop relationships with government ministries, regulatory agencies and other agencies that represent, direct and manage policies affecting supply and demand in different markets. Such relationships should be based on mutual respect, acceptance of specialist work and respect for appropriate responsibilities. In this case, the policy mandate of the various organizations will facilitate communication, assist in the search for alternatives that are less harmful to competition and consumer welfare;

- Competition protection usually carries out public speeches and public speeches to promote or defend positions in favor of competition. However, competition protection should not be controversial; public conflict with other agencies is sometimes risky, difficult, and counterproductive. The preferred strategy for making economic decision-making better and more informed is to encourage discussion and provide accurate information;

- Have a specific expert (or should be able to obtain it from outside experts) in areas where the competition agency will intervene. The agency should propose alternative policy 
measures for competition concerns. Compromises should normally be made so that the state can achieve other socio-economic objectives;

- protection of competition should be carried out in an open, transparent manner so as to protect the inviolability and trust of the competition agency. If confidentiality is required, the Competition Agency should explain the reason for the publication of news;

- protection of competition will be more effective in the case of competition agency isolated from free, political and bureaucratic interference;

- An educated business press is a valuable tool in helping the goals of competition law policies. Competition agencies must establish good media relations and explain the importance and role of competition law as an integral part of the economic structure of the state.

\section{References}

[1] Abbaszada, M., Badalov, T., Shelaginov, O. (2000/2001-2018/2019). Scientific-statistical analysis of the results of admission exams for higher educational institutions for 2000 / 2001-2018 / 2019 academic year. Abiturient, 12, Baku: SSAC. Available at the http://dim.gov.az/upload/iblock/4ae/4aed8eb97c25ce2e4372a46de60595e5.pdf (accessed 16 July 2019)

[2] Antimonopoly legilation of Japan. Tokyo,1998.

[3] Constitution of the Republic of Azerbaijan http://bakubookfair.com/images/pdf/14050630171)\%20Az\%C9\%99rbaycan\%20Respublikas\%C4\% B1n\%C4\%B1n\%20Konstitusiyas\%C4\%B1.pdf

[4] Commission for the Protection of Competition. Sofia 1994;

[5] Protection of competition qanunu. Ankara 1998.

[6] Economic Report of the President Washington, 2000, p. 126-127

[7] Hajiyev N.O.,Studying of special practical issues of abuse of dominance. Journal of Economic Sciences: Theory \& Practice. 2012, Vol. 69 Issue 2, p55-90

[8] Lal K Almas, Hajiyev N.O., Azerbaijan's current and potential comparative advantage: an exploratory study. International Conference on Policy Modeling (EcoMod 2013), Prague, Czech Republic, July p.1-3

[9] Legal regulation of the competition process. New York, 1979, Antimonopoly Law and polices of japan. 1994, Monopoly Policy inthe UK. Cheltenham, 1998, The first international competitionsimposium Turkeye, Istanbul, 1999, Competition Law of the Russian Federation, M. 1999, Competitive and antitrust regulation. M.1999. The 2000 handbook of competition regulators, London, 2000.

[10] Muradov, A.J., Hajiyev N.O.,Competitive environment is the main factor for integration into the world economy. Journal of Economic Sciences: Theory \& Practice. 2014, Vol. 71 Issue 2, p.5-20

[11] Muradov, A.J., Hajiyev N.O., Assessment stages of cyclical development of monopoly and competition in terms of the reconstruction of Azerbaijan economy. Journal of Economic Sciences: Theory \& Practice. 2013, Vol. 70 Issue 1, p.97-117

[12] Muradov A.J., Hasanli Y.H., Hajiyev N.O., (2019). The assesment of impact of competitiveness to economic development. Economic and Social Development: Book of Proceedings, 1170-1177 Publisher: Varazdin Development and Entrepreneurship Agency (VADEA)

[13] Muradov, A.J., Hajiyev N.O., Analytical frameworks and procedures for application of demonopolization. Journal of Economic Sciences: Theory \& Practice. 2014, Vol. 71 Issue 1, p.4-25

[14] Policy directions for global merger review. London. 1999, International competition policy advisory Committee. To the attorney general and assistant attorney general for antitrust. Final report Washington, 2000.].

[15] Remarks by the President at world economic forum. Davos, 2000, (http // www. Pub. Whitehouse. Gov/uri-rest 12 R? urn. Pdi // oma. Lop. g.) United Nations Conference on Trade and Development. Action plan. Bangkong 2000. 